\title{
The live bird trade in Brazil and its conservation implications: an overview
}

\author{
RÔMULO ROMEU NÓBREGA ALVES, JOSÉ RIBAMAR DE FARIAS LIMA \\ and HELDER FARIAS P. ARAUJO
}

\section{Summary}

Brazil's rich biological and cultural diversity makes it an exceptional location for examining the commerce in live wild birds and its implications for conservation. This paper catalogues the live bird species being traded in Brazil, characterises the trade in these animals, and discusses the implications for avian conservation. In spite of being illegal, capturing and selling birds is still a very common practice in Brazil and involves many actors who make up part of a large commercial network that distributes wild animals to every corner of the country. Our survey revealed that at least 295 bird species are illegally sold as pets in Brazil, with estimates derived from this data pointing to a total of more than 400 species - about $23 \%$ of the number of extant bird species in the country. Of the bird species recorded, two were classified as "Critically Endangered", nine as "Endangered", six as "Vulnerable", and 19 as "Near Threatened" according to the most recent IUCN Red List. Most of the species recorded in this study as being widely bought and sold (including on the international market) are not listed by CITES even though many of them are in fact threatened. In light of the widespread illegal trade in wild birds in Brazil and the conservation implications for the species involved, there is an urgent need for actions that can control these activities. Steps should be taken to address the illegal traffic directly and these must include monitoring, law enforcement, effective sentencing (including deterrent sentences), targeting end-users, captive breeding, and education at all levels, taking into account the cultural, economic, social, and ecological aspects of the human populations involved.

\section{Resumo}

A rica diversidade biológica e cultural brasileira faz do país um lugar excepcional para examinar o comércio de aves silvestres e suas implicações para a conservação. O presente trabalho registra as espécies sendo comercializadas no Brasil, caracteriza o comercio destes animais, e discute suas implicações para a conservação de aveifauna. Apesar de ser ilegal, a captura e o comércio de pássaros é uma prática muito comum no país e envolve muitos atores que compoem uma grande rede comercial que distribui animais silvestres para diferentes regiões. Nossa pesquisa revelou que pelo menos 295 espécies diferentes de pássaros são comercializadas ilegalmente no Brasil como animais de estimação, com estimativas apontando para um total de mais que 400 espécies - aproximadamente $23 \%$ do número total de espécies de aves nativas do país. Das espécies registradas, duas estão classificadas como "criticamente ameaçada", nove como "ameaçada", seis "vulnerável" e 19 como "quase ameaçada", segundo a edição mais recente da lista vermelha da IUCN. A maioria das espécies registradas, embora amplamente comercializadas (mesmo no mercado internacional) não estão listadas pela CITES, apesar do fato que muitas consideradas ameaçadas. Considerando o disseminado comércio ilegal de aves silvestres no Brasil e as suas implicações para as espécies envolvidas, existe a necessidade urgente de controlar esta atividade. Medidas devem ser tomadas para combater o trafico ilegal de animais silvestres, incluindo fiscalização rigorosa, medidas legais, ações judiciais (incluindo 
condenações exemplares), medidas legais contra os compradores finais, criação em cativeiro, e medidas educativas em todos os níveis - levando em conta os aspectos culturais, econômicos, sociais e ecológicos das populações envolvidos.

\section{Introduction}

Ancient cultures around the world are known to have caught, kept, and bred birds as pets as long as 4,000 years ago (Collar et al. 2007, Carrete and Tella 2008, Tidemann and Gosler 2010), and the history of the bird trade likewise goes back thousands of years. Indigenous people traditionally kept and used animals in South America, and when Columbus first arrived in the New World he and his crews were met by natives offering skeins of spun cotton and wooden spears tipped with stingray tails, as well as live parrots. Ever since that first contact, parrots and macaws have featured in domestic and international trade in live birds (Thomsen and Brautigam 1991).

Analyses of historical documents indicate that birds have been kept by Indians since ancient times for their beauty, songs, and companionship and bird-keeping is firmly entrenched in local cultures and traditions (Carvalho 1951, Cascudo 1973). The commerce in wild fauna is likewise an ancient practice. Europeans who came back from exploratory journeys in the $16^{\text {th }}$ century would bring back unknown animals to mark their deeds and as evidence of having discovered new continents (Sick 1997). The first recorded specimens of the Brazilian wild fauna sent to Europe date from 1500 (Polido and Oliveira 1997), and began the commercial exploitation of the Brazilian fauna which was perceived as abundant and virtually inexhaustible (Renctas 2001).

Brazil has one of the most diverse avian faunas in the world, with 1,832 known species (CBRO 2011), which amounts to about $57 \%$ of the bird species recorded for all of South America (Marini and Garcia 2005). Unfortunately, the country has the highest number of threatened bird species within the Neotropics (Collar et al. 1997), with 189 species listed as threatened (IUCN 2011) and 160 bird taxa that are nationally threatened (Silveira and Straube 2008). Illegal trade in animals is the greatest threat to the Brazilian wild fauna after habitat loss and subsistence hunting (Redford 1992, Rocha 1995, Marini and Garcia 2005). Birds are currently the most important group involved in wild animal trafficking in Brazil. While the conservation implications of international wild bird trading have received considerable attention, little is actually known about the bird trade at the national level (Alves et al. 2010). This is particularly true in the Neotropics, where wild birds are frequently captured for both national and international markets (Robinson and Redford 1991, Gonzalez 2003). The Glaucous Macaw Anodorhynchus glaucus and Spix's Macaw Cyanopsitta spixii are examples of species that became extinct largely because of this illegal commerce (Marini and Garcia 2005).

Bird-keeping activities are common throughout Brazil in both rural and urban settings (Sick 1997). These birds rarely come from legal breeders, however, and are mostly captured in the wild (Gama and Sassi 2008, Alves et al. 2010). Most bird species are traded for pets, although a few species are traded for food and (to a far lesser extent) medicinal and folk magic purposes (Alves and Rosa 2007, 2010, Alves 2009, Alves and Alves 2011).

There are very few published data on the extent of the domestic trade in birds in Latin American countries, but there are indications that it involves a substantial portion of the birds captured in the wild and current control mechanisms within these countries are insufficient to eliminate poaching (Desenne and Strahl 1991, Thomsen and Brautigam 1991, Thomsen and Mulliken 1992, Renctas 2001, Weston and Memon 2009, Gastañaga et al. 2011). Without detailed information on the species traded and the numbers of specimens involved, it is impossible to judge accurately the impact of this commerce. Brazil's rich biological and cultural diversity makes it an exceptional location for examining the trade in live wild birds and its implications for wildlife conservation. As such, the present paper catalogues the live bird species being traded in Brazil, and characterises the trade in these animals and discusses the implications for avian conservation. 


\section{Methods}

To examine the bird trade within Brazilian cities, we reviewed all the available references and reports on this topic. Information was gathered from published articles, books and book chapters, theses and dissertations, as well as from reports available in international online databases such as Science Direct (www.sciencedirect.com), Scirus (www.scirus.com), Google Scholar, Scopus (www.scopus.com), Web of Science (www.isiknowledge.com), and Biological Abstracts (science. thomsonreuters.com) using the following search terms: - Wild birds + Trade + Brazil — Birds + Commercialization + Brazil,- Wildlife trade + Brazil,- Birds + Pet trade + Brazil and Keeping birds + trade + Brazil.

Only taxa that could be identified to the species level were included in the database. The scientific nomenclature of the species cited in this study follows the guidelines of the South American Classification Committee (Remsen et al. 2011). The conservation status of the bird species follows IUCN (2011) and the Brazilian Red List (Silveira and Straube 2008); information concerning international trade regulations was extracted from CITES (2011). A database was created containing information on the bird species, family names, and the cities where their use was recorded.

The species identified at the 17 survey sites were used to prepare an accumulation curve of the species involved in bird trafficking. The Jackknife 1 technique was used to estimate the numbers of bird species traded in Brazil as our data bank is composed of information gleaned from bibliographic references and this method uses incidence to generate its estimates. This technique has been successfully utilised by many authors to estimate bird species richness as well as the richness of known birds from interview data (Araujo and Nishida 2007, Araujo 2009). The Jaccard similarity index was used to examine the clustering of bird species among the 15 recorded trade sites. A matrix was constructed using presence/absence data of the species identified at these sites to quantify their similarity and, consequently, the clustering among the areas to search for geographical and/or cultural patterns of bird trade activities in Brazil. The Teresina-PI locality was not used in this analysis due to the preliminary nature of the research undertaken there; the birds of Paraíba State were not considered in these analyses because three cities were represented in that state.

The sources analysed and cities surveyed are presented in Table 1 and Figure 1 .

\section{Results}

\section{Numbers and diversity of commercially-traded species}

Our survey revealed that at least 295 bird species belonging to 177 genera and 56 families are illegally traded as pets in Brazil (Appendix $\mathrm{S}_{1}$ in the online supplementary material), with estimates derived from these data pointing to a total of more than 400 species (Figure 2) - about $23 \%$ of the extant bird species in the country. This estimate may be far from comprehensive, however, as studies on illegal trade are limited and because the legal implications of keeping and selling wild birds makes gathering information from informants more difficult.

The family with the largest number of traded species was the Emberizidae ( $16.3 \%$ of recorded species), followed by Psittacidae (15.06\%), Thraupidae (8.6\%), and Icteridae (6.7\%).

While a large variety of species are traded, not all species are equally valued. One measure of species popularity would be the number of surveys in which a given species was noted in local trading networks. The species most cited in the surveys, in descending order, were: Saffron Finch Sicalis flaveola (recorded in 16 localities), Lined Seedeater Sporophila lineola (15), Red-cowled Cardinal Paroaria dominicana (15), Capped Seedeater Sporophila bouvreuil (13), Blue-black Grassquit Volatinia jacarina (13), Rufous-bellied Thrush Turdus rufiventris (12), White-throated Seedeater Sporophila albogularis (12), Ultramarine Grosbeak Cyanocompsa brissonii (11) Yellowbellied Seedeater Sporophila nigricollis (II), Blue-fronted Parrot Amazona aestiva (II), Sayaca tanager Thraupis sayaca (II), White-naped Jay Cyanocorax cyanopogon (10), Pileated Finch Coryphospingus pileatus (10), White-bellied Seedeater Sporophila leucoptera (10), Yellow-winged 
Table 1 . The sites where surveys were undertaken, the numbers of species encountered, with the respective references.

\begin{tabular}{llcl}
\hline City/state or State & Region & Species recorded & Source \\
\hline O1- Fortaleza, CE & Northeast & 57 & Costa (2005) \\
O2- Baturité, CE & Northeast & 33 & Fernandes-Ferreira et al. (2010) \\
03- Itapipoca, CE & Northeast & 20 & Assis and Lima (2007) \\
04- Teresina, PI & North & 10 & Rodrigues et al. (2007) \\
05- Campina Grande, PB & Northeast & 21 & Rocha et al. (2006) \\
06- Paraíba & Northeast & 98 & Pagano et. al. (2010) \\
07- João Pessoa, PB & Northeast & 18 & Gama and Sassi (2008) \\
08 - Recife, PE & Northeast & 102 & Pereira and Brito (2005) \\
09- Feira de Santana, BA & Northeast & 72 & Santos and Costa-Neto (2007) \\
10- Paraguaçu, BA & Northeast & 38 & Souza and Soares Filho (1998) \\
11- Juiz de Fora, MG & Southeast & 75 & Borges et al. (2006) \\
12- Rio de Janeiro, RJ & Southeast & 50 & Padrone (2004) \\
13- Santa Maria, RS & South & 77 & Zago (2008) \\
14- Rio Grande do Sul & South & 90 & Ferreira and Glock (2006) \\
15- Goiás & Central-West & 78 & Bastos et al. (2010) \\
16- Cuiabá, MT & Central-West & 16 & Pinho and Nogueira (2000) \\
17- Belém, PA & North & 60 & Moreira (1997) \\
\hline
\end{tabular}

Blackbird Agelaius thilius (10), Blue-winged Parrotlet Forpus xanthopterygius (10), and Doublecollared Seedeater Sporophila caerulescens (9).

Considering the entire set of species recorded in the study sites, similarity analysis identified three distinct groups (Figure 3): 1) a regional group comprising Amazonian localities that are characterised by shared Amazonian taxa; 2) a group comprising 10 sites in north-eastern and south-eastern Brazil that demonstrated great similarity in terms of the species traded; and 3) a group comprising central and southern sites.

The choice of species that are traded is influenced by inter- and intraspecific factors. Species are chosen for the beauty of their plumage as well as for the quality of their song. Another important factor in the bird trade is rarity. Intraspecific factors that influence the choices of traded species include their sex (males are usually more valuable because they are the best singers) and how long they have been domesticated (since domesticated birds sing more than recently captured birds).

The chain of commercial interactions begins with the capture of wild birds. Suppliers in rural upland and farmland areas capture birds using various techniques, including cages, bird nets, traps and other implements, and bait such as grain or fruit, water or lures (previously captured song birds). Birdlime, normally prepared from the sap of fruit trees (jackfruit Artocarpus sp., mangaba Hancornia speciosa) and faveleira Cnidoscolus phyllacanthus, is also used. The use of torches at night to dazzle birds in their nests is also commonly used and among the species captured using this technique are Campo Troupial Icterus jamacaii, Cyanocompsa brissonii, Yellow-faced Siskin Sporagra yarrellii, Sporophila albogularis, and Paroaria dominicana - birds widely sought after and sold as pets, mainly in north-eastern Brazil. In addition to capturing adult birds, many hunters gather nestlings to raise in captivity.

Once captured, the birds are sold at low prices in their rural source areas and subsequently resold in small cities or further transported for sale in large urban centres.

Most birds are delivered to end-sellers by middlemen in cities who take the specimens to public markets and fairs. These public markets are the principal trade points for wild birds and other animals. In spite of well-know legal implications, occasional raids, and the seizure of animals (with the arrests of the businessmen involved), these underground markets still function throughout Brazil within socio-economic and cultural contexts that current laws cannot impede. Because of the inherent secrecy involved in the trade of wild birds, it has been almost impossible to obtain 


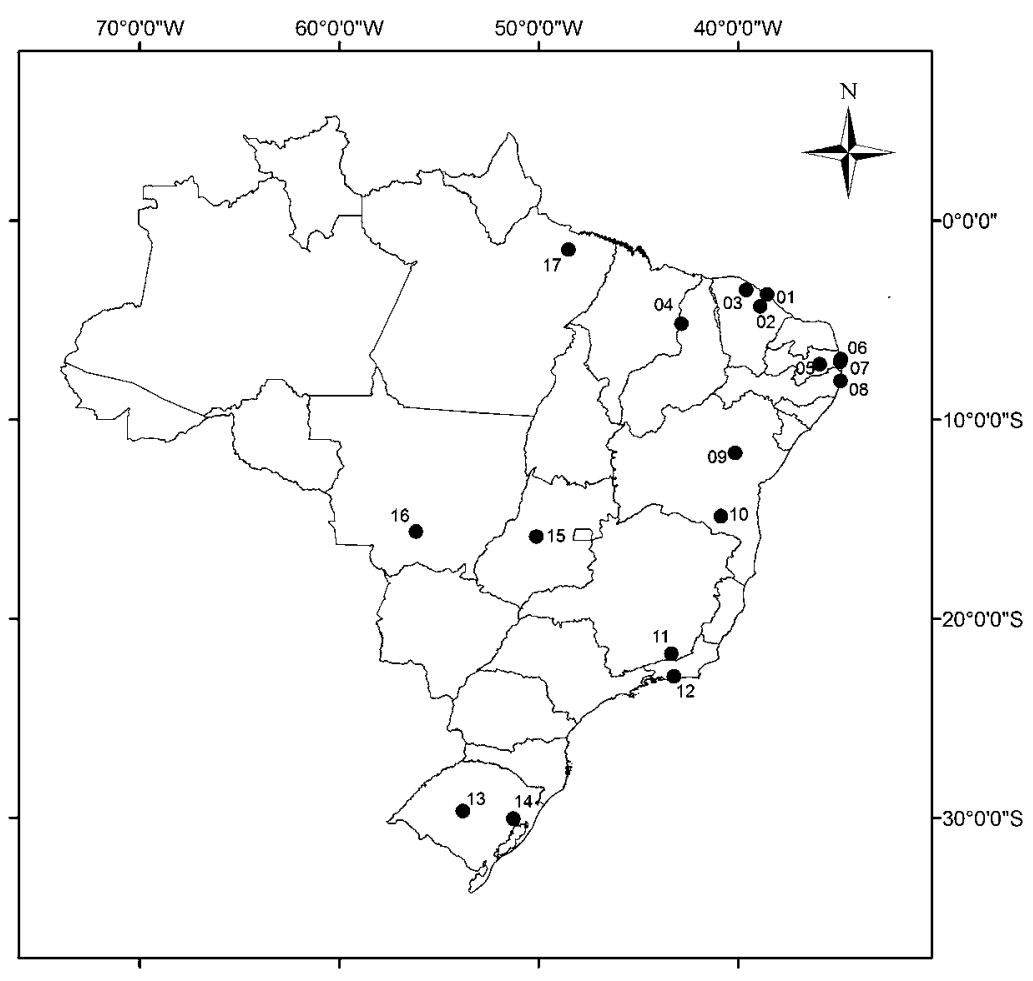

Figure 1 . Sites of live bird commerce in Brazil. The numbers correspond to the localities listed in Table 1.

detailed information about the activities of wholesalers and breeders placing a serious constraint on conservation initiatives.

The birds suffer high levels of mortality in the first days of captivity, and costs rapidly rise at the buyer level. Another reason for the observed variations in price is the risk involved in transportation and in the later stages in the trade. As this is, of course, an illegal business, the middlemen run the risk of being identified and punished with fines and imprisonment. Prices thus remain low when a bird is trapped and sold locally, but if the same bird is transported to a distant market its price will rise dramatically.

The illegal commerce in wild animals has recently acquired a new ally - the internet - and many websites advertise the sale of wildlife specimens in Brazil. At first glance, most of these sites sell only species that are permitted by Brazilian legislation and all of them cite environmental laws and declare that all the animals have appropriate documentation. However, even birds that are threatened with extinction can be found for sale on these sites.

Of the bird species recorded in our review, two species were classified as "Critically Endangered", nine as "Endangered", six as "Vulnerable", and 19 as "Near Threatened" in the most recent IUCN Red List. These results demonstrate the need to assess the implications of the trade in birds on wild populations, and to include this in discussions of bird conservation.

Brazil has committed itself to the conservation of its wildlife through the adoption of national and international legislation and as a signatory of the Convention on International Trade in Endangered Species of Wild Flora and Fauna (CITES). However, illegal trade continues to flourish openly throughout the country. Among the birds found to be traded in Brazil, only 32 species were listed in the CITES Appendices (Appendix $\mathrm{S}_{1}$ in the online supplementary material), 


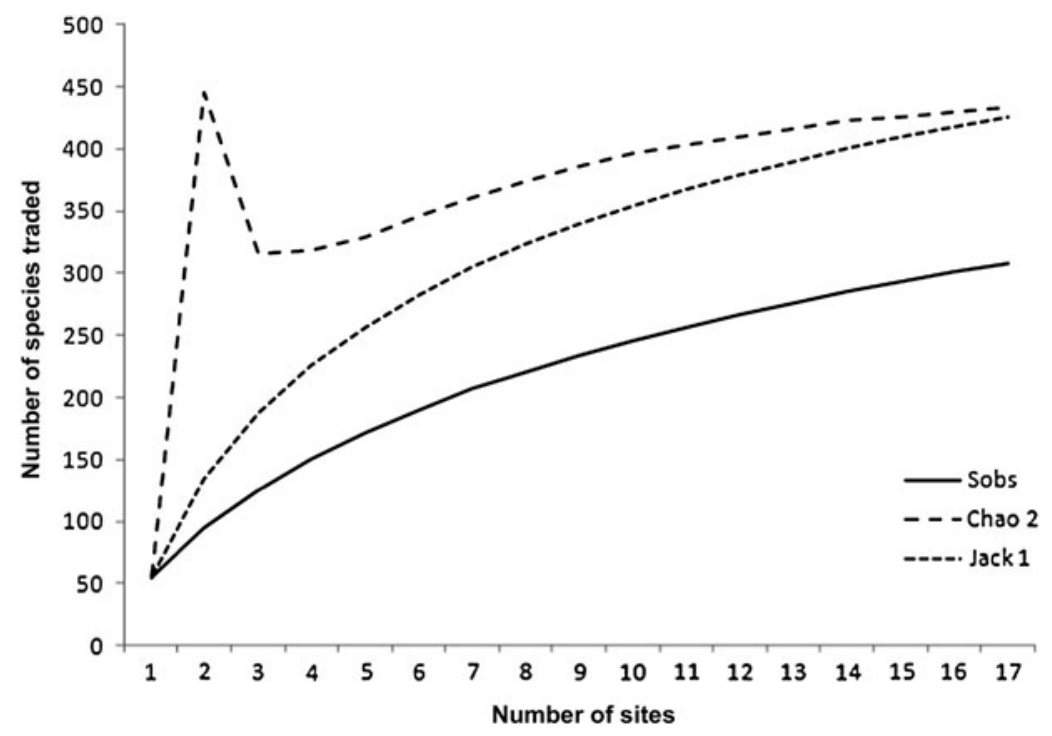

Figure 2. Numbers of bird species traded (Sobs) derived from surveys in 17 sites in Brazil, with the estimated total numbers of birds traded (Chao 2 and Jack 1 ). Note axes: $\mathrm{x}=$ sites $\mathrm{y}=$ bird species traded

including 11 species listed on Appendix I, 17 species on Appendix II, and four species on Appendix III. So most of the species recorded in this study as being widely bought and sold (including on the international market) are not listed by CITES even though many of them are in fact threatened.

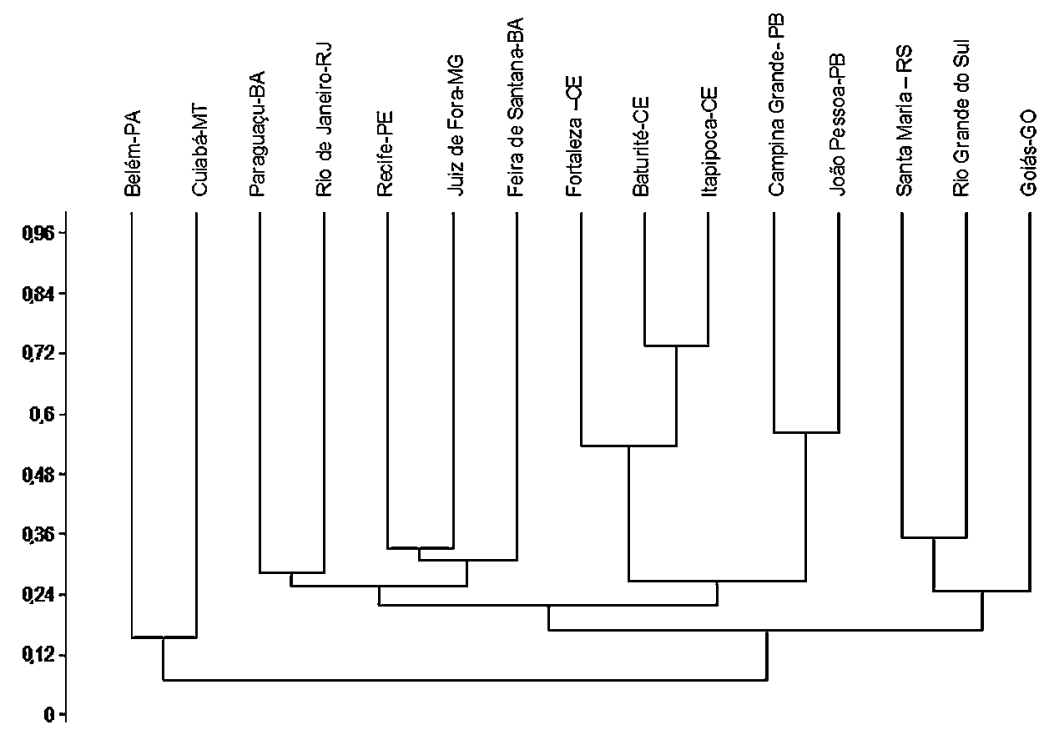

Figure 3. Similarity matrix clusters using Jaccard's index of the trade bird species composition in 16 Brazilian sites. 


\section{Discussion}

The illegal capture and trade of wild birds is widespread throughout Brazil and, as has been shown in the present study, involves large numbers of species. The high taxonomic diversity among traded birds is not surprising given that birds represent the most traded group among all animals involved in trafficking in Brazil (Renctas 2001, Alves et al. 2010). Our results indicated that species of the families Emberizidae and Psittacidae stood out among the taxa of wild birds traded as pets in Brazil, corroborating a trend reported in previous studies (e.g. Shepherd 2006, FAO 2008, Godoy and Matushima 2010, Gastañaga et al. 2011).

There are many reasons for the observed preference for species in these families. The Emberizidae are favoured as cage birds as they are extremely hardy, are granivorous, their small size allows a large numbers of them to be kept together in small cages, and they have popular appeal due to their colourful plumage (Frisch and Frisch 1981, Sick 1997). The Psittacidae are the world's most popular pet birds due to their capacity to imitate human voices as well as their intelligence, beauty, and docility - being second only to dogs and cats in overall popularity (Hardie 1987, Fitzgerald 1989, Santos 1990, Hemley 1994, Sick 1997, Alves et al. 2010).

Corroborating the findings of earlier studies on the trade in wildlife products (e.g. Adeola 1992, Alves and Rosa 2008, 2010), the prices of wild birds bought and sold in Brazil are very variable and reflect various criteria such as the species, singing ability, sex, market demand, size, and rarity. The latter aspect assumes enormous importance in terms of biodiversity conservation. The overexploitation of rare and endangered species may result in their extinction in the wild - with people who greatly value rarity furnishing increasingly large economic incentives to capture increasingly rare specimens (Courchamp et al. 2006, Angulo et al. 2009). The vulnerability of rare species has been well publicised for some very charismatic birds, but many others are affected. Many species will become rare in the near future, and some could rapidly disappear simply because they suddenly are considered fashionable to one given market segment or another (Angulo et al. 2009).

Most of the species encountered in our study are locally common or widely distributed throughout Brazil (Stotz et al. 1996, Ridgely and Tudor 2009). The fact that birds common to any given region are those most frequently found in captivity suggests that besides the colours and songs of the birds, access seems to directly influence the prevalence of such species being kept as pets (Alves et al. 2010). It is known, however, that the trade in wild birds in Brazil involves commercial routes through many different states and it is relatively easy to buy species far from where they normally occur. Species native to the north-eastern part of the country (such as Paroaria dominicana and Icterus jamacaii) are widely sold in the northern and southern states, and Amazonian species such as Moriche Oriole Icterus chrysocephalus are likewise sold in the south-east.

Most of the wild animals illegally traded in Brazil come from the northern, north-eastern, and mid-western regions and are transported to the southern and south-eastern parts of the country (Renctas 1999), mainly along highways in trucks, buses, and cars, as shown in the charts below. Only in the northern (Amazonian) region of Brazil are animals transported along river routes. The major destinations of these birds are the states of Rio de Janeiro and São Paulo, where they are either sold in fairs or, largely, exported to Europe, Asia, and North America through major ports and airports (Renctas 2001).

The journeys of wild birds from their source to the final consumer involve a wide range of intermediaries. The chain of activities includes a number of different groups that can be basically classified as follows: suppliers, middlemen, and consumers (Carvalho 1985, Lopes 1991, Hemley 1994, Rocha 1995, Le Duc 1996, Renctas 2001, Alves et al. 2010). Because Brazil is highly socially heterogeneous and profoundly unequal in terms of income distribution, socioeconomic aspects play an important role in the wildlife trade (Alves and Rosa 2010). Additionally, the activities of wild bird traders are very lucrative in the context of high unemployment rates and low levels of formal education in Brazil - a situation not uncommon in developing countries.

It is worth stressing that the majority of the captured animals die before ever reaching their final destinations. Despite the existence of various transportation options, animals are still kept in 
extremely limited and overcrowded spaces and supplied with neither water nor food. Under these conditions birds often fight, mutilating and killing each another. It has been estimated that at least three specimens are lost for each animal product traded; among live animals, this figure is even higher - only one out of ten animals captured survives (Redford 1992). The principal causes of mortality include: 1) wounded animals dying after escaping; and 2) damaged animals being discarded because they are considered 'below standard' (Redford 1992). Passerine females, such as tanagers Tangara spp. are often killed soon after being captured as they have little commercial value (Nogueira and Capivara 1973). With the exception of the very rare and valuable specimens, all trafficked animals are treated poorly and nearly $80 \%$ of all captured birds end up dying (Toufexis 1993).

Following a strong tendency noted in earlier studies (e.g. Warchol et al. 2003; Wu 2007), the internet represents a powerful medium for selling illegal wild birds in Brazil. A survey carried out by Renctas in 1999 found 4,892 advertisements in Brazilian and international sites promoting the illegal sale and exchange of wild animals from the Brazilian fauna. Most were advertisements for birds and reptiles, but mammals, amphibians, and ornamental fish were also offered (Renctas 2001). The internet must be viewed with considerable alarm because of the efficiency with which virtual markets allow buyers and sellers to connect with ease and speed that was never before possible (Wu 2007). These vast potential markets pose new challenges to legislators and enforcement agencies.

\section{Implications for conservation}

Multiple factors have contributed to significant declines in global bird populations, but one of the principal causes has been identified as illegal commerce (Collar et al. 1997, García-Moreno et al. 2007, Weston and Memon 2009, Alves et al. 2009, 2010). Capture for trade purposes was considered the primary cause of the extinction of Spix's Macaws in the wild, and it is currently the most endangered species of Psittacidae. The illegal trade in Psittacidae is still very profitable but devastating for some species (Fitzgerald 1989). The Hyacinth Macaw Anodorhynchus hyacinthinus, for example, is mainly threatened by a large and persistent illegal trade. At least 10,000 of these birds were taken from the wild in the 1980s, and $50 \%$ of them were absorbed by the Brazilian market (Mittermeier et al. 1990). Similarly, Golden Parakeet Guaruba guarouba is trapped for trade and is highly sought after by both international and national markets. There is a well-organized internal trade of Red-spectacled Amazon parrots Amazona pretrei, and these birds are usually taken by cutting down their nest-tree, resulting in the permanent abandonment of that nesting site. Although it was formerly fairly common, Sun Parakeet Aratinga solstitialis was extirpated from much of its former range by trapping for the cage bird trade, and it is now in urgent need of effective protection. Many other parrot species may likewise become threatened if illegal trading is allowed to continue.

Various species of the family Emberizidae have been impacted by the illegal commerce in wild birds. The constant and chronic harvesting of Yellow Cardinal Gubernatrix cristata as a songbird for the cage-bird market remains the most significant threat to this species. Persecution of Buffyfronted Seedeater Sporophila frontalis for the pet trade is severe, and lots containing 100-200 birds have been seen for sale in Rio de Janeiro (BirdLife International 2008). The greatest threat to Temminck's Seedeater Sporophila falcirostris is the excessive capture and illegal trade in this species; and together with $S$. frontalis; these are the two most common species seen in cages along the coast of Paraná State. Species from other families besides the Psittacidae and Emberizidae are also being pressured by illegal trading.

The illegal trade in wild birds in Brazil is widespread and there is an urgent need to implement actions to control these activities. These actions must take into account the cultural, economic, social and ecological aspects of the human populations involved. Steps should be taken to directly address the illegal traffic in wild animals and must involve monitoring, law enforcement, effective sentencing (including deterrent sentences), targeting end-users, captive breeding, and education at various levels.

There is a need for better enforcement at the main trading points, principally in public markets. Some of these locations have never been inspected due either to complacency or a lack 
of information available to the wildlife authorities. One of the justifications presented by these authorities for their slowness in acting is that these market activities usually take place on weekends when their agents have their days off (Costa 2005) - a simple but important aspect that must be taken into consideration in planning suppression activities. Monitoring and control, however, should not be restricted to trading sites in urban areas, but should also be extended to the principal roads that carry illicit wildlife products, as well as airports and bus stations in urban centres that function as important hubs for sending and receiving illegal animal shipments. The illegal commerce in wild animals over the internet should likewise be rigorously investigated. While Brazilian legislation concerning the commerce in wild animals is considered adequate, the lack of sufficient monitoring and the inexistence of effective plans or practices against trafficking allow this illegal activity to continue throughout the country. Imposing prison penalties for smugglers would probably be an effective way to reduce this illegal trade (and Federal Law already stipulates punishment of six months to one year for infractions of that type) but prison terms are rarely handed out and smugglers often simply return to their activities.

Commercial breeding has been encouraged in countries like Indonesia to replace the capture of wild birds (Jepson and Ladle 2005). The licensing and regulation of breeders by the Brazilian Institute of Environment (IBAMA) was implemented in order to reduce harvesting from wild populations. Captive breeding of popular species in Brazil is not currently seen as a viable alternative to illegal trade in wild birds because: 1 ) many specimens declared to be captive-bred were actually born in the wild and legalised through the falsification of bird rings; and 2) the price of a commercially-bred bird is now approximately ten times higher than a wild-caught individual (Renctas 2001, Alves et al. 2010), making it unlikely that commercial breeding could replace the wild bird trade in many communities, particularly in low-income areas.

Campaigns that combat animal trafficking by focusing on the final consumer must also be intensified. Media campaigns can be used to discourage purchases of wild birds and to expose problems such as the cruelty involved in capture and mortality during transportation and disease transmission to humans (Renctas 2001). In addition to radio and television appeals, we would recommend the use of posters, stickers, videos and comic strips in schools, libraries, universities, airports, markets, and other public spaces where large numbers of people circulate (FernandesFerreira et al. 2012).

Environmental education programmes designed to create a national culture that supports environmental protection could potentially change public attitudes regarding wild birds as pets. These programmes could be carried out locally by training community organisers in areas where bird-keeping activities are prevalent, or more widely through environmental education programmes linked to Brazil's national curriculum. This is particularly feasible given that public schools are nationally organised. Raising public awareness about the threats that bird-keeping poses to natural populations will also complement and improve the effectiveness of the approaches described earlier (e.g. more rigorous law enforcement and commercial breeding) (Alves et al. 2010). Keeping birds as pets has high cultural value in many localities in Brazil, so intense educational efforts will be essential in sending out the message that keeping wild animals is illegal (a fact that is unknown to a significant fraction of the population) and that there are feasible alternatives - such as visiting zoos, birdwatching, or adopting other domestic pets. Finally, one of the most important aspects is the way Brazilians view the question of wild animal trafficking - for most people do not view wild animal trafficking as an ethical or moral problem, and this awareness must be introduced into the public consciousness.

One of the largest challenges to bird conservation in the Neotropics is reconciling and integrating both human and conservation needs (Grajal and Stenquist 1998). Within this context, and in order to achieve sustainability in the use of wild species, it is necessary to establish which species are being captured, and to understand the socioeconomic and cultural significance of their use and commercialisation. Considering the economic and cultural importance of birds, studies that combine biological inventories with local knowledge can aid in developing strategies for management and conservation (Alves et al. 2010). 
The problem of dealing with the people engaged in illegal wildlife trafficking needs to be examined in a humane way. Perhaps this traditional expertise in bird trapping and breeding can be constructively utilised for scientific management and wildlife studies. North-eastern trappers, for example, have accumulated a considerable volume of knowledge about hill birds that has not yet been fully documented (Alves et al. 2010). This knowledge can be an important source of information about the regional avifauna, and these trappers could be used by researchers as field guides. The rehabilitation of bird trappers into alternative jobs, at least for the individuals who coordinate the local commerce in these species, would be an important step in reducing illegal trading. Conservation awareness would also need to be passed on to illiterate trappers, and this would function best if they were given alternative work/compensation, as in many cases catching birds is an important (or only) source of income for these people.

Combined with the great diversity of species in Brazil are great diversities of threats to biodiversity in general and birds in particular. As such, education and enforcement are the most important immediate actions that must be undertaken in the country, but they must also be integrated with programmes that can protect wildlife habitats - which will benefit not only birds but other animal groups as well.

\section{Supplementary Material}

The online supplementary materials for this article can be found at journals.cambridge.org/bci

\section{Acknowledgements}

The first author would like to thank CNPq (Conselho Nacional de Desenvolvimento Científico e Tecnológico) for providing a research fellowship.

\section{References}

Adeola, M. O. (1992) Importance of wild animals and their parts in the culture, religious festivals, and traditional medicine, of Nigeria. Environ. Conserv. 19: 125-134.

Alves, R. R. N. (2009) Fauna used in popular medicine in Northeast Brazil. J. Ethnobiol. Ethnomed. 5: 1-30.

Alves, R. R. N. and Alves, H. N. (2011) The faunal drugstore: Animal-based remedies used in traditional medicines in Latin America. J. Ethnobiol. Ethnomed. 7: 1-43.

Alves, R. R. N. and Rosa, I. L. (2007) Zootherapy goes to town: The use of animalbased remedies in urban areas of NE and N Brazil. J. Ethnopharmacol. 113: 541-555.

Alves, R. R. N. and Rosa, I. L. (2008) Use of Tucuxi Dolphin Sotalia fluviatilis for Medicinal and Magic/Religious Purposes in North of Brazil. Hum. Ecol. 36: 443-447.

Alves, R. R. N. and Rosa, I. L. (2010) Trade of animals used in Brazilian traditional medicine: trends and implications for conservation. Hum. Ecol. 38: 691-704.
Alves, R. R. N., Mendonça, L. E. T., Confessor, M. V. A., Vieira, W. L. S. and Lopez, L. C. S. (2009) Hunting strategies used in the semiarid region of northeastern Brazil. J. Ethnobiol. Ethnomed. 5: 1-50.

Alves, R. R. N., Nogueira, E., Araujo, H. and Brooks, S. (2010) Bird-keeping in the Caatinga, NE Brazil. Human Ecology 38: 147-156.

Angulo, E., Deves, A. L., Saint Jalmes, M. and Courchamp, F. (2009) Fatal attraction: rare species in the spotlight. Proc.R. Soc. B: Biol. Sci. 276: 1331-1337.

Araujo, H. (2009) Amostragem, estimativa de riqueza de espécies e variação temporal na diversidade, dieta e reprodução de aves em área de caatinga, Brasil. PhD. Thesis. Universidade Federal da Paraíba.

Araujo, H. and Nishida, A.K. (2007). Conhecimento de pescadores artesanais sobre a composição da avifauna em estuários paraibanos: uma contribuição para conservação. Sitientibus 7: 67-77. 
Assis, I. A. D. and Lima, D. C. (2007) Uma introdução ao comércio ilegal de aves em Itapipoca, Ceará. VIII Congresso de Ecologia do Brasil. Caxambu, Mato Grosso.

Bastos, L. F., Luz, V. L. F., Reis, I. J. and Souza, V. L. (2010) Apreensão de espécimes da fauna silvestre em Goiás-situação e destinação. Rev. Biol. Neotrop. 5: 51-63.

BirdLife International 2008. Sporophila frontalis. In: IUCN 2011. IUCN Red List of threatened species. Version 2011.2. <www. iucnredlist.org > . Downloaded on o3 March 2012.

Borges, R. C., de Oliveira, A., Bernardo, N. and da Costa, R. (2006) Diagnóstico da fauna silvestre apreendida e recolhida pela Polícia Militar de Meio Ambiente de Juiz de Fora, MG (1998 e 1999). Rev. Brasil. Zoociênc. 8: $23-33$.

Carrete, M. and Tella, J. L. (2008) Wild-bird trade and exotic invasions: a new link of conservation concern? Frontiers Ecol. Environ. 6: 207-211.

Carvalho, C. E. S. (1985) Lista preliminar da fauna comercializada na feira de Caxias - RJ. Boletim Fundação Brasileira para a Conservação da Natureza 20: 90-102

Carvalho, L. C. M. (1951) Relações entre os indios do Alto Xingu e a fauna regional. Rio de Janeiro: Publicações Avulsas do Museu Nacional.

Cascudo, L. C. (1973) Civilização e cultura: Pesquisa e notas de etnografia geral. Rio de Janeiro: José Olímpio, 1973.

CBRO-Comitê Brasileiro de Registros Ornitológicos (2011) Listas das aves do Brasil.1oa. Edição. Downloaded from <http://www. cbro.org.br> on 09/2011.

CITES (2011) Appendices I, II and III. Downloaded from http://www.cites.org/eng/app/ e-appendices.pdf.

Collar, N. J., Long, A. J. and Jaime, P. R. G. (2007) Birds and people: Bonds in a timeless journey. Cambridge, UK: BirdLife International.

Collar, N. J., Wege, D. C. and Long, A. J. (1997) Patterns and causes of endangerment in the New World avifauna. Ornithol. Monogr. 237-260.

Costa, R. G. A. (2005) Comércio ilegal de aves silvestres em Fortaleza, Ceará. Atualidades Ornitológicas 125: 1-3.
Courchamp, F., Angulo, E., Rivalan, P., Hall, R. J., Signoret, L., Bull, L. and Meinard, Y. (2006) Rarity value and species extinction: the anthropogenic Allee effect. PLoS Biol 4: e415.

Desenne, P. and Strahl, S. (1991) Trade and the conservation status of the family Psittacidae in Venezuela. Bird Conserv. Internatn. 1: 153-169.

FAO (2008) International trade in wild birds (and other relevant movements) in Latin America and the Caribbean. Rome, Italy: Food and Agriculture Organizations of the United Nations.

Fernandes-Ferreira, H., Mendonça, S. V., Albano, C., Ferreira, F. S. and Alves, R. R. N. (2010) Comércio e criação de aves silvestres (Psittaciformes, Piciformes e Passeriformes) no Estado do Ceará. Pp. 381-402 in R. R. N. Alves, W. M. S. Souto and J. S. Mourão, eds. A Etnozoologia no Brasil: importância, status atual e perspectivas futuras Recife: NUPEEA.

Fernandes-Ferreira, H., Mendonça, S. V., Albano, C., Ferreira, F. S. and Alves, R. R. N. (2012). Hunting, use and conservation of birds in Northeast Brazil. Biodiversity and Conservation (21): 221-244.

Ferreira, C. M. and Glock, L. (2006) Diagnóstico preliminar sobre a avifauna traficada no Rio Grande do Sul, Brasil. Biociências 12: 21-30.

Fitzgerald, S. (1989) International wildlife trade: whose business is it? Washington DC: World Wildlife Fund.

Frisch, J. D. and Frisch, S. (1981) Aves Brasileiras. Volume 1. São Paulo, Brazil: Editora Dalgas-Ecoltec Ecologia Técnica e Comércio.

Gama, T. F. and Sassi, R. (2008) Aspectos do comércio Ilegal de Pássaros Silvestres na Cidade de João Pessoa, Paraíba, Brasil. Gaia Scientia 2: 1-20.

García-Moreno, J., Clay, R. P. and RíosMuñoz, C. A. (2007) The importance of birds for conservation in the Neotropical region. J. Ornithol. 148: 321-326.

Gastanñaga, M., Macleod, R., Hennessey, B., Nuñez, J. U., Puse, E., Arrascue, A., Hoyos, J., Chambi, W. M., Vasquez, J. and Engblom, G. (2011) A study of the parrot trade in Peru and the potential importance of internal trade 
for threatened species. Bird Conserv. Internatn. 21: 76-85.

Godoy, S. N. and Matushima, E. R. (2010) A survey of diseases in passeriform birds obtained from illegal wildlife trade in São Paulo City, Brazil. J. Avian Med. Surgery 24: 199-209.

Gonzalez, J. A. (2003) Harvesting, local trade, and conservation of parrots in the Northeastern Peruvian Amazon. Biol. Conserv. 114: 437-446.

Grajal, A. and Stenquist, S. (1998) Research applications for bird conservation in the Neotropics. Pp. 337-343 in J. M. Marzluff and R. Sallabanks, eds. Avian conservation: research and management. Washington, DC: Island Press.

Hardie, L. C. (1987) Wildlife trade education kit. Washington, DC: WWF, TRAFFIC.

Hemley, G. (1994) International wildlife trade: a CITES sourcebook. Washington: WWF/Island Press.

IUCN (2011) The IUCN Red List of threatened species. Version 2010.3. Downloaded from www.iucnredlist.org

Jepson, P. and Ladle, R. J. (2005) Bird-keeping in Indonesia: conservation impacts and the potential for substitution-based conservation responses. Oryx 39: 442-448.

Le Duc, J. P. (1996) Trafficking in animals and plants: a lucrative form of crime. International Criminal Police 458: 19-31.

Lopes, P. R. D. (1991) Comércio de animais silvestres. Bioikos 5: 49-56.

Marini, M. A. and Garcia, F. I. (2005) Bird conservation in Brazil. Conserv. Biol. 19: 665-671.

Mittermeier, R. A., Gusmão Câmara, I., Pádua, M. T. J. and Blanck, J. (1990) Conservation in the Pantanal of Brazil. Oryx 24: 103-112.

Moreira, C. F. (1997) Comércio ilegal das aves silvestres vivas nas principais feiras da cidade de Belém, Pará, Brasil. Bélem: Universidade Federal Rural da Amazônia.

Nogueira, N. and Capivara, P. (1973) A criacao de animais indígenas vertebrados. Sao Paulo: Edições Tecnapis.

Padrone, J. M. B. (2004) O comércio ilegal de animais silvestres: avaliação da questão ambiental no Estado do Rio de Janeiro. Rio de Janeiro: Universidade Federal Fluminense.
Pagano, I. S. A., Sousa, A. E. B. A., Wagner, P. G. C. and Ramos, R. T. C. (2010) Aves depositadas no Centro de Triagem de Animais Silvestres do IBAMA na Paraíba: uma amostra do tráfico de aves silvestres no estado. Ornithologia 3: 132-144.

Pereira, G. A. and Brito, M. T. (2005) Diversidade de aves silvestres brasileiras comercializadas nas feiras livres da Região Metropolitana do Recife, Pernambuco. Atualidades Ornitológicas 126:

Pinho, J. B. and Nogueira, F. M. B. (200o) Mostra da retirada de psitacídeos em cativeiro na cidade de Cuiabá e Pantanal de Poconé, Mato Grosso, no período 1995-1997. Ararajuba 8: 51-53.

Polido, A. P. and Oliveira, A. M. M. (1997) O comércio ilegal de animais silvestres no Brasil. São Paulo: Faculdades Integradas São Camilo.

Redford, K. H. (1992) The empty forest. BioScience 42: 412-422.

Remsen, J. V. Jr., Cadena, C. D., Jaramillo, A., Nores, M., Pacheco, J. F., Pérez-Emán, J., Robbins, M. B., Stiles, F. G., Stotz, D. F. and Zimmer, K. J. (2011) A classification of the bird species of South America. American Ornithologists' Union. http://www.museum. lsu.edu/ Remsen/SACCBaseline.html

Renctas (1999) Animais silvestres: normatização e controle. Rio de Janeiro: Rede Nacional Contra o Tráfico de Animais Silvestres.

Renctas (2001) $I^{0}$ relatório nacional sobre o tráfico de fauna silvestre. Brasília: Rede Nacional Contra o Tráfico de Animais Silvestres.

Ridgely, R. S. and Tudor, G. (2009) Field guide to the songbirds of South America: the Passerines. Austin, Texas: University of Texas Press.

Robinson, J. G. and Redford, K. H. (1991) Neotropical wildlife use and conservation. Chicago: University of Chicago Press.

Rocha, F. M. (1995) Tráfico de animais silvestres no Brasil. Brasília, DF: WWF.

Rocha, M. S. P., Cavalcanti, P. C. M., Sousa, R. L. and Alves, R. R. N. (2006) Aspectos da comercialização ilegal de aves nas feiras livres de Campina Grande, Paraíba, Brasil. Revista de Biologia e Ciências da Terra 6: 204-221.

Rodrigues, A. M. D., Carvalho, A. S. D. and Brito, J. S. (2007) Análise do comércio de animais silvestres em Teresina-PI. II 
Congresso de Pesquisa e Inovação da Rede Norte Nordeste de Educação Tecnológica. João Pessoa. Paraíba, Brazil.

Santos, E. (1990) Da ema ao beija-flor. Belo Horizonte: Editora Villa Rica.

Santos, I. B. and Costa-Neto, E. M. (2007) Estudo etnoornitológico em uma região do semi-árido do Estado da Bahia. Sitientibus Série Ciências Biológicas 7: 273-288.

Shepherd, C. R. (2006) The bird trade in Medan, North Sumatra: an overview. Birding Asia 6: 16-24.

Sick, H. (1997) Ornitologia Brasileira. Rio de Janeiro: Nova Fronteira.

Silveira, L. F. and Straube, F. C. (2008) Aves ameaçadas de extinção no Brasil. Pp. 378-669 in A. B. M. D. Machado, G. M., and Paglia, A. P., ed. Livro Vermelho da Fauna Brasileira ameaçada de extinção. Brasília: Fundação Biodiversitas, Ministério do Meio Ambiente.

Souza, G. M. and Soares Filho, A. (1998) Comércio ilegal de aves silvestres na região do Paraguaçu e sudoeste da Bahia. Enciclopédia Biosfera 1: 1-11.

Stotz, D. F. J. W., Fitzpatrick, T., Parker, I., Moskovits, D. K. (1996) Neotropical birds: ecology and conservation. Chicago: University of Chicago Press.

Thomsen, J. B. and Brautigam, A. (1991) Sustainable use of neotropical parrots. Pp. $359-380$ in J. G. Robinson and K. H. Redford, eds. Neotropical wildlife use and conservation Chicago: University of Chicago Press.

Thomsen, J. B. and Mulliken, T. A. (1992)

Trade in Neotropical psittacines and its conservation implications. Pp. 359-379. in S. R. Beissinger and N. F. R. Snyder, eds. New World parrots in crisis: solutions from conservation biology. Washington DC: Smithsonian Institution Press.

Tidemann, S. and Gosler, A. (2010) Ethnoornithology: Birds, indigenous people, culture and society. London, UK: Earthscan/ James \& James.

Toufexis, A. (1993) All God's creatures priced to sell. Time 142: 36-41.

Warchol, G. L., Zupan, L. L. and Clack, W. (2003) Transnational criminality: An analysis of the illegal wildlife market in Southern Africa. Internatn. Criminal Justice Rev. 13: 1

Weston, M. K. and Memon, M. A. (2009) The illegal parrot trade in Latin America and its consequences to parrot nutrition, health and conservation. Bird Populations 9: 76-83.

$\mathrm{Wu}, \mathrm{J} .(2007)$ World without borders: Wildlife trade on the Chinese-language internet. Traffic Bull. 21: 75-84.

Zago, D. C. (2008) Animais da fauna silvestre mantidos como animal de estimação. Santa Maria: Programa de Pós Graduação em Educação Ambiental. Universidade Federal de Santa Maria.

\section{RÔMULO ROMEU NÓBREGA ALVES*, JOSÉ RIBAMAR DE FARIAS LIMA}

Departamento de Biologia, Universidade Estadual da Paraíba, Av. das Baraúnas, 351 / Campus Universitário, Bodocongó, 58109-753, Campina Grande-PB, Brazil.

\section{HELDER FARIAS P. ARAUJO}

Departamento de Ciências Biológicas, Centro de Ciências Agrárias, Universidade Federal da Paraíba, Areia, Paraíba 58397-ooo, Brazil.

*Author for correspondence; e-mail: romulo_nobrega@yahoo.com.br

Received 21 September 2011; revision accepted 20 February 2012; Published online 16 July 2012 